\title{
AMERICA'S ENCOUNTERS
}

\section{WITH SOUTHEAST ASIA, 1800-1900: BEFORE THE PIVOT}

\author{
by Farish $A$. Noor \\ (A Book Review)
}

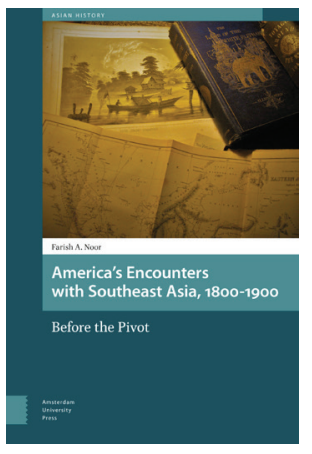

—arish Noor's latest book presents a series - of richly-textured critical explorations of a selection of key texts presenting windows on the ways in which the United States engaged with a range of different Asian societies over the course of the nineteenth century. The author emphasizes from the outset that this is "a book about books"-pursuing a series of close readings to explore the ways in which these texts reflect emerging and contested visions of a distinctively American identity constructed in relation to perceptions of diverse others that U.S. citizens found themselves in contact with on the distant shores of Southeast Asia in the nineteenth century. The particular books treated here thus serve to reveal different facets of America's evolving image and its relationships to an expanding world of foreign relations over the first century of the nation's history. The story begins with a bang.

Noor's readings of the two accounts of the voyage of the U.S. Frigate Potomac published in 1835 by Francis Warriner and Jeremiah Reynolds, respectively, present overlapping narratives of the young nation's first act of military aggression in Asia. This took place at the Sumatran port of Quallah-Battoo (Kuala Batu), located on the west coast of the island in what is today the Indonesian province

R. Michael Feener University of Oxford United Kingdom

(i) 
Indigenous Social Movements in the Americas

of Aceh. It was there that the Friendship of Salem, Massachusetts anchored to procure a cargo of pepper in February 1831. By that time, such sailings had become rather routine, building up a booming trade that started with the phenomenally profitable return on the first cargo of Sumatran pepper brought to Salem in 1797. The experience of the crew of the Friendship on this errand was, however, strikingly different and ended violently. While the ship's captain was ashore, locals who were presented as porters to load his vessel with pepper overwhelmed the crew of the Friendship, killing the First Mate and two crew members, and seizing the ship. After the Captain and other survivors finally returned Stateside, news of the attack sparked public outrage, pressuring Congress to dispatch the USS Potomac to exact redress for the attack on the ship from Salem. This culminated in the punitive bombardment of Quallah-Battoo, which in turn further fueled fiery partisan political debate back home.

Two men on board for the expedition of this heavily-armed frigate to Southeast Asia produced popular books on the voyage upon their return. While the basic narratives of both agree on nearly every major point, their respective accounts of those events reveal somewhat different perspectives and interpretations of what the voyage meant as a projection of American power abroad. Noor characterizes the account of Francis Warriner-a "non-combatant" officer on the Potomac-as more "religious" and "moral" in tone, presenting a rather ambivalent report on America's first military adventure in Asia. Noor contrasts this with Jeremiah Reynolds' sharper and more defensive tone on the attack of Quallah-Battoo as justified by the need of the United States to project protection of its citizens and their property even while overseas.

A separate chapter in Noor's book later returns to the ongoing saga of Quallah-Battoo with a discussion of FitchW. Taylor's account of the circumnavigation of two U.S. naval vessels, in the course of which they received news of another attack on an American trading vessel anchored off of that same pepper port in 1838. In response, they adjusted course to investigate, and, when talks broke down with the local rajah, the Americans once again bombarded the Sumatran coast, devastating both Quallah-Battoo and the nearby port of "Muckie" (Meukek). Taylor's text presents a complex and often contrasting assemblage of reflections ranging 
from fantasizing about the possibility of the American colonization of Sumatra to asserting America's unique nature of being above such foreign adventurism and an aestheticized relish in the violence of gunboat interventions.

The tension between professions of innocence of imperial ambitions and threats of the use of force to advance national interests abroad takes on further permutations in the other works discussed here by Noor. Edmund Roberts' Embassy to the Eastern Courts of Cochin-China, Siam and Muscat (1837) records the travels of an American "Special Agent" sent on the USS Peacock to gather intelligence and his eventual success in negotiating the first treaty between the United States and a Southeast Asian sovereign power. Noor's characterization of the book as both a record of an early chapter in diplomatic history and marking "the birth of American Orientalism in Southeast Asia" (82) further highlights the complexity and simultaneous expression of multiple registers of discourse that such early texts of American experience in Southeast Asia present.

Over the decades that followed, American entanglements in Southeast Asia grew increasingly complex through both official arrangements such as the 1850 American-Brunei Treaty and independent adventurism. A particularly fascinating instance of the latter is examined by Noor through his nuanced reading of Walter Murray Cibson's 1855 The Prison of Weltevreden-a complex work of fiction that incorporated and embellished material from the author's report on his time in Sumatra intended for the U.S. government. While Gibson travelled to Southeast Asia independently and without any official mandate or sanction, he became embroiled in a significant international incident when a letter surfaced in which Gibson wrote to the Sultan of Jambi purportedly instigating rebellion against the Dutch colonial authorities and pledging American naval support. After that debacle, Gibson went on to other adventures that in themselves continued to intersect in significant ways with evolving imaginations of America and its place in this world (and the next) through stints as both a Mormon missionary and Prime Minister of the Kingdom of Hawaii.

The last book treated in a chapter-length discussion is Albert S. Bickmore's account of his voyage to the East Indies (Travels in the East Indian Archipelago, 1869)-representing an early American attempt 
to establish the nation's international scientific reputation. That book also, however, reflected emerging ideas on race that came to animate American interventions in Asia and the treatment of Asians in the United States for more than a century. From there, Noor surveys the increasing production of American travel writing and Orientalist literature as emblematic of the nation's "coming of age" on the global stage. Through Noor's selection and exploration of this generally forgotten literature, this book presents a story of America in Southeast Asia that predates the turn of the twentiethcentury colonization of the Philippines. In this, it provides a critical and insightful complement to the familiar narrative of the development of U.S. foreign policy in the region punctuated by a series of "wars": the Spanish-American, and two World Wars, as well as one "Cold" one.

Thus, while Noor frames this book as primarily a work of "literary and discourse analysis" (14), the book also sheds important light on the histories of both America and Southeast Asia in the nineteenth century. His observations demonstrate they ways in which these publications can be read as artefacts of processes of identity formation, in which early American voices began to articulate a vision of what distinguished them from other "Westerners" in their interactions with diverse Asian "others". Through his careful and contextualized readings, these texts emerge as remarkable points for reflection on historical processes that contributed to the formation of America's

Indigenous Social Movements in the Americas national identity alongside the roles that Southeast Asia as a region and its people played within that.

Noor's book is also valuable in providing a number of appendices that will prove useful to students and scholars of American and Southeast Asian history during this period, including the full texts of major treaties between the United States and Asian powers: Siam (1833), Brunei (1850), and Japan (1854), as well as a helpful timeline of America's nineteenth-century entanglements with Asia. Taken as a whole, then, this book makes valuable contributions to several fields that do not often intersect in a single academic work: Southeast Asian history, nineteenth-century literature, and American studies. Readers coming from the perspective from any of these fields will learn much from Noor's book, and his finely crafted prose helps to make it a thoroughly enjoyable read as well. 
WORKS CITED

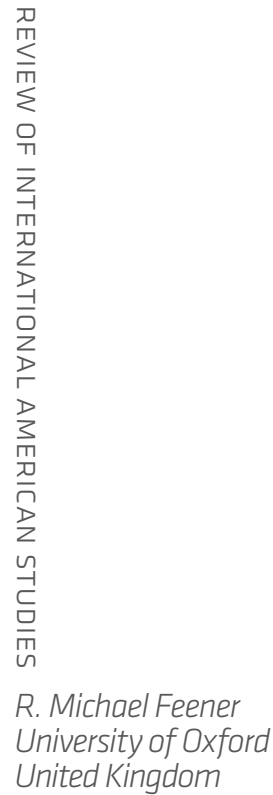


